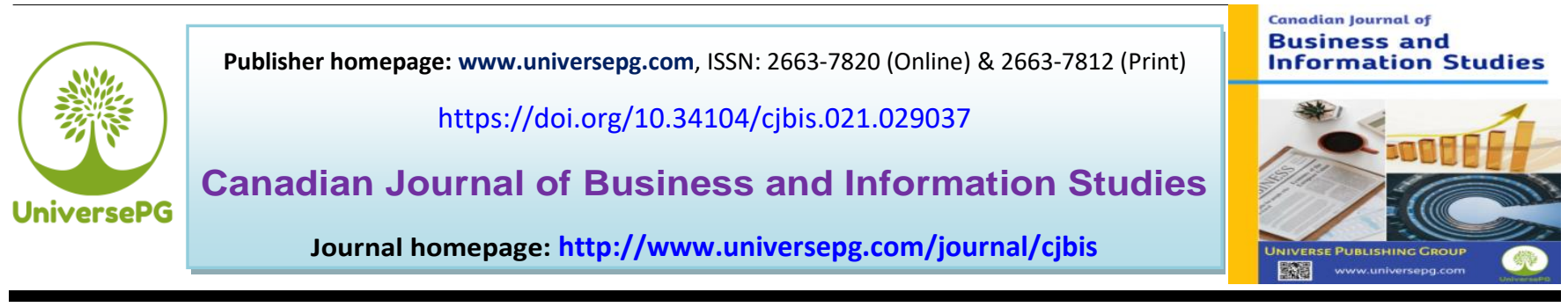

\title{
The Reasons that Affect the Implementation of HR Analytics among HR Professionals
}

\author{
Batuol Ramzi Ali Alsuliman ${ }^{1}$ and Musaddag Elrayah ${ }^{2 *}$ \\ ${ }^{1 \& 2}$ Department of Management, School of Business, King Faisal University, P.O Box: 400, Al-Ahsa, 31982, Saudi Arabia. \\ *Correspondence: melrayah@kfu.edu.sa (Musaddag Elrayah, Department of Management, School of Business, King Faisal \\ University, Al-Ahsa, 31982, Saudi Arabia).
}

\begin{abstract}
Today, organizations use digital applications to enhance their HR operations, especially during the COVID-19 pandemic. Many organizations compete to improve business performance as well as having a competitive advantage in their business areas. The business strategic plans depend on business' facts and data that support these plans. HR analytics promises to provide evidence-based initiatives, data-driven decision making, prioritize the impact of HR investments and enhance the business value and performance. This study tries to gain insights into the reasons for not using HR analytics among Saudi HR professionals to enhance business performance and maintain a competitive advantage. It uses the descriptive survey research design. This paper focuses on the individual-level adoption of HR analytics by human resource professionals. The main objective of this paper is to understand the importance of HR analytics and to gain insight into the barriers that affect the full implementation of HR Analytics among Saudi HR professionals. The total population used in this study is 168 HR professionals who work in the Dairy Products Manufacturing Companies in Saudi Arabia. The primary data used in this study collected through the Unified Theory of Acceptance and Use of Technology (UTAUT) questionnaire, which was sent through the work's official email, WhatsApp, and LinkedIn to the target sample. The study finds positive relationships between HR analytics adoption and the other factors. Also, the results show the main barriers that affect the implementation of HR Analytics by Saudi HR Professionals.
\end{abstract}

Keywords: Reasons, HR analytics, Performance, HRA implementation, Operations, and HR professionals.

\section{INTRODUCTION:}

Today, the Saudi Arabian society is living in a modern era and enjoying a welfare life, unlike the simple nomad life dominated in the past years. Lately, the evolution, transformation, and change are even greater after the introduction of vision 2030 in late April 2015. The establishment of the KSA under one ruler, Oil exploration, and the need for inexpensive and safe oil sources after World War-II for the rebuilding of
Europe, which enhanced the Saudi Arabian oil Industry, and shaped the Saudi economy's current structure. In the Arabian Peninsula before the discovery of oil, the concept of the labor force was different from Western societies. It did not exhibit a clear division of classes and it was limited to application. Most of the Saudi people were engaged in self-employment or practicing traditional types of working (Al-Asmari, 2008). 
The focus of this paper is to explore the perception of HR professionals about HR analytics and the factors that affect the adoption of HR analytics among them. This study tries to cover the perception of Saudi HR professionals working on dairy products manufacturing companies in Saudi Arabia. It focuses on the factors that affect the implementation of HR analytics among HR professionals. Saudi Arabia is the biggest producer of dairy products compared with other Gulf Cooperation Council (GCC) countries. This due to the highest per capita level in Saudi Arabia.

This paper is important because it covers the adoption of HR analytics by HR professionals. Today, organizations use digital applications to enhance their HR operations, especially during the COVID-19 pandemic. It provides recommendations to improve the adoption level of HR analytics. The findings of this study are expected to fill the gap in the literature especially that related to the HR analytics adoption among HR professionals in Saudi Arabia.

\section{Literature Review}

HR Analytics - Organizations view human capital as a significant factor in corporate development and economic growth, in addition to being a source of competitive advantage (Delery \& Roumpi, 2017). Organizations are competing to attract, select, retain and motivate talented employees (Andrijević Matovac et al., 2010). The business environment and our lives are affected by digitalization. The world of business is depending heavily on technology. Conducting business without technology will be impossible during these years (BarNir et al., 2003). The huge increase and availability of data amount, storing techniques, and processing speed are contributing to the development of technology and positively affecting organizations and the systems of work (Strassmann, 1985). Having high-volume data along with the analytics tools helped organizations making data-driven decisions and forecasting in different aspects and areas (Angrave et al., 2016).

The data-driven decisions used to support decisionmaking in human resource management (HRM) and the availability of big data is considered as the opportunity for potential growth in the field of HR analytics (Milon, 2019). Many studies have shown that under- standing Human Resources Analytics (HRA) and leveraging it in daily operations improve the datadriven HRM and support the business function. The adoption and implementation of analytics have been growing and likely to continue in the HR field (FitzEnz \& John Mattox, 2014). Many organizations today believe that human capital management (HCM) is one of the most valuable assets in all business operations. Analytics offers great managerial support for managing human capital (Levenson \& Fink, 2017). Organizations can attain a competitive advantage when acepting and using HRA. HRA will enable organizations to build a better link for hiring and retaining top talent. However, failure of accepting HRA will affect the organization's competitive advantage adversely (Minbaeva, 2018).

Some of the factors, which affect the acceptance of using these innovations in HR, include the lack of business intelligence and mathematical knowledge that HR professionals have lack of understanding the quantitative data and not being able to deal with it (FitzEnz, 2010). The decision that is taken based on evidence drawn from data analysis is more likely to be better than an intuition-based decision. Accepting to use HR analytics will enable organizations to build a better link for hiring and retaining top talent through supporting the HRM dissection making process. On the contrary, they fail to use HR analytics will negatively affect the organization's competitive advantage (Fitz-Enz, 2010). HR analytics promises to provide evidence-based results, decisions based on data, prioritize the impact of HR investments, and enhance the business value and performance (Hoque et al., 2020). Thus, the present study aims to gain insights into the reasons for not using HR analytics among Saudi HR professionals to enhance business performance and maintain a competitive advantage. The development of human capital (HC) will play a major role in the Saudi Vision of 2030. Following the vision, 450,000 new jobs will be created by the end of the year 2020. From now up to fifteen years, the unemployment rate expected to reduce from $11.6 \%$ to $7 \%$, and the Saudi labor force will approximately reach 8.6 million. Estimation shows that Saudis entering the labor market will drastically as an average of 203 thousand jobs is needed to accomplish the vision of 2030. HR analytics adoption 
will enable organizations to build a better link for hiring and retaining top talent and will help in supporting the HRM dissection making process (FitzEnz, 2010).

Organizations are considering $\mathrm{HC}$ as an important source of competitive advantages and it's essential for business development (Andrijević Matovac et al., 2010; Pradana et al., 2020). According to Rasmussen \& Ulrich, (2015), many organizations are still not taking advantage of using HR analytics or still at the early stages of implementation. The number of the published papers that HR analytics is enhancing business strategies and value creation is weak. Organizations rarely share success stories of the impact of HR analytics on business performance. However, to the contrary, Google, IBM, and some companies like them have already taken bigger steps in the area of analytics to get a head start. The available examples are few and more research is required on how organizations get affected by implementing HR analytics (Kim, Dibrell, Kraft, \& Marshall, 2021; Rasmussen \& Ulrich, 2015; Zhou, Liu, Chang, \& Wang, 2021). As stated by many publishers, using HR analytics will increase an organi- zation's productivity and enhance its overall value. Although, very few HR experts enrolled in this process. This work aims to discover the hindrance and barriers to adopting HR analytics among Saudi HR professionals.

HR Professionals - There are international standards that impact hiring, orienting, promoting, training, and assessing HR professionals (Ulrich et al., 2013). HR professionals use to provide organizations with assistant and guidance that comply with the international people management standards. Today, many HR certification bodies like the Chartered Institute of Personnel Development (CIPD), the Society of Human Resource Management have developed their professional map that design to cover the main knowledge areas, skills, and competencies required by the HR profession. Many factors affect HR professionals include the technological impact (Acemoglu \& Restrepo, 2019; Kochan, 2007; Parry \& Strohmeier, 2014). Besides, the HR profession is faced with many challenges that might affect its existence in the future (Guest \& Conway, 2011; Kochan, 2004; Rucci, 1998; Tzafrir et al., 2007).

\section{The Conceptual Model of the Research}

Independent Variables (IVs)

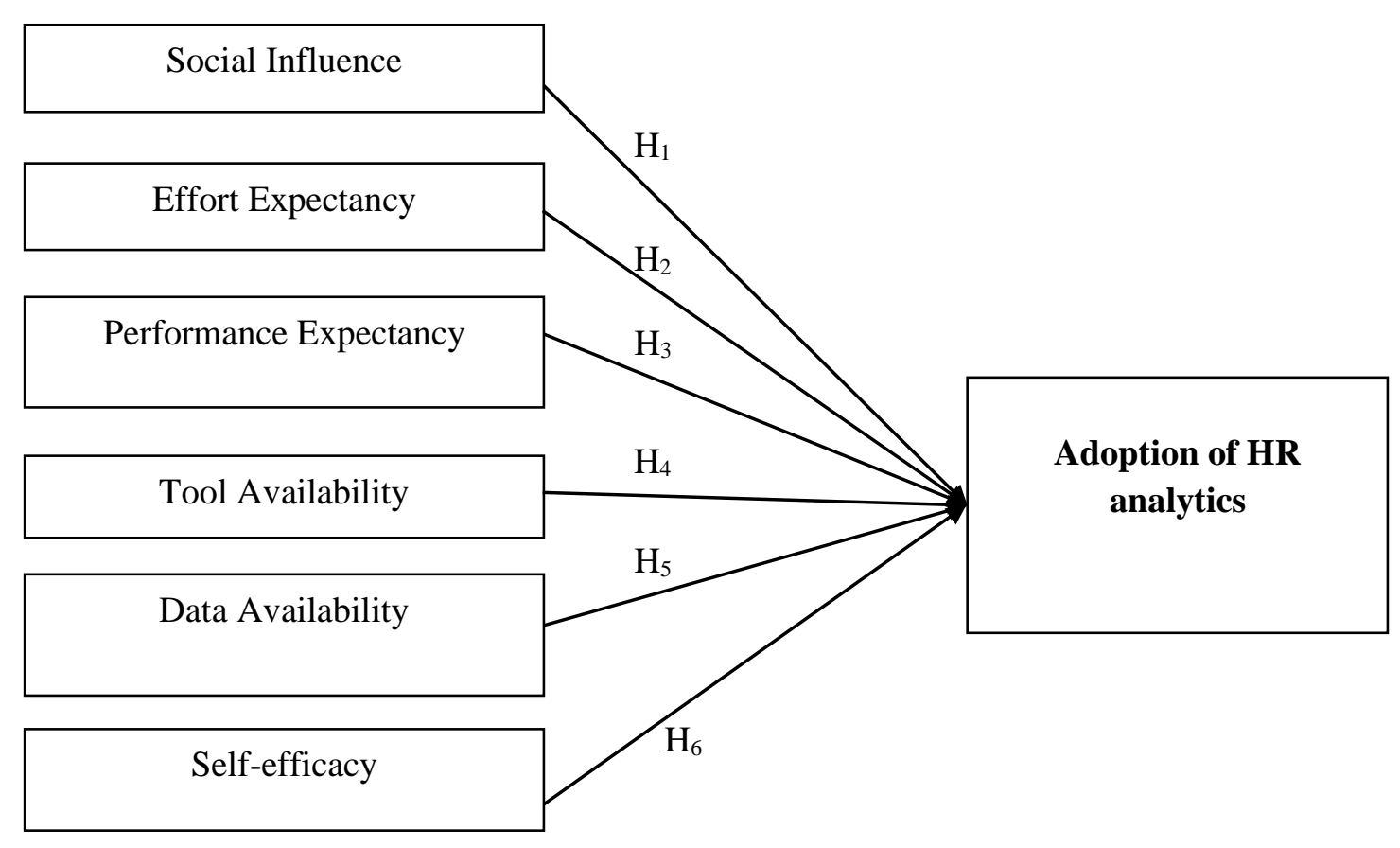

Fig1: Conceptual model of the research. 
$\mathrm{H}_{1}$ : There is a relationship between the selfefficacy factor and the adoption of using HR analytics.

$\mathrm{H}_{2}$ : There is a relationship between the social influence factor and the adoption of using HR analytics.

H3: There is a relationship between the social influence factor and the adoption of using HR analytics.

H4: There is a relationship between the tool availability factor and the adoption of using HR analytics.

H5: There is a relationship between the data availability factor and the adoption of using HR analytics.

H6: There is a relationship between the selfefficacy factor and the adoption of using HR analytics.

\section{METHODOLOGY:}

This study uses a descriptive survey research design. It uses quantitative data. A questionnaire was used to find the reasons affecting HR professionals in adopting HRA. The UTAUT questions were sent to the Saudi HR professionals who are working in the dairy products manufacturing companies in Saudi Arabia. A questionnaire was sent through emails, WhatsApp, and LinkedIn to the target sample. The total population of this study was $168 \mathrm{HR}$ professionals.

This study has used Steven K. Thompson's, (2012) sampling formula to identify the sampling size from total population. The equation suggested as follows:

$$
n=\frac{N * p(1-p)}{\left[\left[N-1 *\left(\frac{d^{2}}{Z^{2}}\right)\right]+p(1-p)\right]}
$$

Where, the sample size is $\mathbf{n}$, the total population is $\mathbf{N}$, $\mathbf{Z}$ is the confidence level at $95 \%, \mathbf{d}$ is the error proportion (0.05) and $\mathbf{p}$ is the probability ( $\mathrm{S}$. Thompson, 2012). The sample used in this study was 117 HR professionals.

The primary data collected to explore the relationship between the adoption of HR analytics and the following factors: effort expectancy, performance expectancy, social influence, tool availability, data availability, and self-efficacy. The questionnaire was sent to each employee personally to answer through social media applications (WhatsApp \& LinkedIn), through work email (colleagues of the researcher), or through calling the staff and asking them, the needed questions to fill the questionnaire. The questionnaire was developed according to the Unified Theory of Acceptance and Use of Technology (UTAUT) and modified by the researchers using the Google survey form. The data collected and analysed using statistical software (SPSS).

\section{RESULTS AND FINDINGS:}

The Demographic Analysis - The below table shows that about 117 HR professionals have completed and returned the questionnaire which represents about $100 \%$ of the total sample. The Table 1 shows that about $43.6 \%$ of the respondents are female, while $56.4 \%$ are male. The Saudis represent $97.4 \%$ of the total sample that used in this study. About $59 \%$ of the respondents have a bachelor's degree, $29.9 \%$ have a diploma, $3.4 \%$ have a doctorate, $6.8 \%$ have master's degrees and only 0.9 have other qualifications.

All respondents are working in the main HR areas and the majority of them $(79.5 \%)$ have more than five years' experience in the HR profession.

Table 1: Demographic Characteristics of the Respondents

\begin{tabular}{|c|c|c|}
\hline Characteristics & Frequency & Percentage \\
\hline $\begin{array}{ll}\text { Age } & \\
& 25-35 \\
& 36-45 \\
& 46-55 \\
& \text { Over } 56 \\
\end{array}$ & $\begin{array}{c}38 \\
45 \\
32 \\
2\end{array}$ & $\begin{array}{c}32.5 \\
38.5 \\
27.4 \\
1.7\end{array}$ \\
\hline $\begin{array}{l}\text { Gender } \\
\qquad \begin{array}{l}\text { Female } \\
\text { Male }\end{array}\end{array}$ & $\begin{array}{l}51 \\
66\end{array}$ & $\begin{array}{l}43.6 \\
56.4\end{array}$ \\
\hline $\begin{array}{l}\text { Nationality } \\
\text { Non-Saudi } \\
\text { Saudi }\end{array}$ & $\begin{array}{c}3 \\
114 \\
\end{array}$ & $\begin{array}{c}2.6 \\
97.4 \\
\end{array}$ \\
\hline $\begin{array}{l}\text { Education } \\
\qquad \begin{array}{l}\text { Bachelor's } \\
\text { degree } \\
\text { Diploma } \\
\text { Doctorate } \\
\text { Master's } \\
\text { degree } \\
\text { Other }\end{array}\end{array}$ & $\begin{array}{c}69 \\
35 \\
4 \\
8 \\
1\end{array}$ & $\begin{array}{c}59.0 \\
29.9 \\
3.4 \\
6.8 \\
0.9\end{array}$ \\
\hline
\end{tabular}


The Descriptive Analysis - This study was conducted on the participants mentioned earlier, to measure the correlations between the dependant variable (Adoption of HRA) and the 6 independent variables (Social Influence, Self-Efficacy, Tool Availability, Data Availability, Performance Expectancy, and Effort Expectancy).

\section{Adoption of HRA}

Pearson Correlation Analysis - The Pearson correlations were tested for the single new value of each independent variable with the dependent variable's new value to determine the contribution of each IV on individual adoption of HR analytics. The tables below summarize the results where $\boldsymbol{r}$ indicates the Pearson correlation coefficient, $\boldsymbol{n}$ indicates the total responses, $\boldsymbol{t}$ statistics equals $=\frac{r * \sqrt{n-2}}{\sqrt{1-r^{2}}}, \boldsymbol{D F}$ indicates the decrease of freedom.

$H_{1}$ : There is a relationship between the self-efficacy factor and the adoption of using HR analytics.

Table 2: Correlation between self-efficacy and HRA adoption

\begin{tabular}{|c|c|c|}
\hline \multicolumn{2}{|c|}{} & Self-Efficacy \\
\hline \multirow{4}{*}{$\begin{array}{c}\text { Adoption of } \\
\text { HRA }\end{array}$} & $\begin{array}{c}\text { Pearson Correlation } \\
\text { Coefficient }\end{array}$ & 0.6211 \\
\cline { 2 - 3 } & $\mathrm{n}$ & 117 \\
\cline { 2 - 3 } & $\mathrm{t}$ statistics & 8.4985 \\
\cline { 2 - 3 } & $\mathrm{DF}$ & 115 \\
\cline { 2 - 3 } & $p$-value (2-tailed) & 0.0000 \\
\hline
\end{tabular}

The p-value equals 0.000 which indicates that the observations are inconsistent with the null hypothesis (The null hypothesis states that there is no relationship between self-efficacy and HRA adoption), the null hypothesis can be rejected (Table 2).

$\mathrm{H}_{2}$ : There is a relationship between the social influence factor and the adoption of using HR analytics.

As shown in the table above, the Pearson correlation between the two variables equals 0.6607 which indicates a positive relationship between the social influence factor and the adoption of HR analytics (Table 3).

UniversePG I www.universepg.com
Table 3: Correlation between social influence and HRA adoption

\begin{tabular}{|l|c|c|}
\hline \multicolumn{1}{|c|}{} & Social Influence \\
\hline \multirow{4}{*}{$\begin{array}{l}\text { Adoption } \\
\text { of HRA }\end{array}$} & $\begin{array}{c}\text { Pearson Correlation } \\
\text { Coefficient }\end{array}$ & 0.6607 \\
\cline { 2 - 3 } & $\mathrm{n}$ & 117 \\
\cline { 2 - 3 } & $\mathrm{t}$ statistics & 9.4395 \\
\cline { 2 - 3 } & $\mathrm{DF}$ & 115 \\
\cline { 2 - 3 } & $p$-value (2-tailed) & 0.0000 \\
\hline
\end{tabular}

The p-value equals 0.000 which indicates that the observations are inconsistent with the null hypothesis (The null hypothesis states that there is no relationship between social influence and HRA adoption), the null hypothesis can be rejected (Table 3).

$H_{3}$ : There is a relationship between the tool availability and the adoption of using HR analytics.

Table 4: Correlation between tool availability and HRA adoption

\begin{tabular}{|l|c|c|}
\hline \multicolumn{2}{|c|}{} & Tool Availability \\
\hline \multirow{4}{*}{$\begin{array}{l}\text { Adoption } \\
\text { of HRA }\end{array}$} & $\begin{array}{c}\text { Pearson Correlation } \\
\text { Coefficient }\end{array}$ & 0.6673 \\
\cline { 2 - 3 } & $\mathrm{n}$ & 117 \\
\cline { 2 - 3 } & $\mathrm{t}$ statistics & 9.6089 \\
\cline { 2 - 3 } & $\mathrm{DF}$ & 115 \\
\cline { 2 - 3 } & $p$-value (2-tailed) & 0.0000 \\
\hline
\end{tabular}

As shown in the table above, the Pearson correlation coefficient value between the two variables equals 0.6673 which indicates a positive relationship between the tool availability factor and the adoption of HR analytics. The p-value equals 0.000 which indicates that the observations are inconsistent with the null hypothesis (The null hypothesis states that there is no relationship between tool availability and HRA adoption), the null hypothesis can be rejected (Table 4).

$H_{4}$ : There is a relationship between the data availability and the adoption of using HR analytics.

As shown in the table above, the Pearson correlation coefficient values between the two variables equal 0.6474 which indicates a positive relationship between the data availability factor and the adoption of HR analytics (Table 5). 
Table 5: Correlation between data availability and HRA adoption

\begin{tabular}{|l|c|c|}
\hline \multirow{4}{*}{$\begin{array}{l}\text { Adoption } \\
\text { of HRA }\end{array}$} & $\begin{array}{c}\text { Pearson Correlation } \\
\text { Coefficient }\end{array}$ & Data Availability \\
\cline { 2 - 3 } & $\mathrm{n}$ & 0.6474 \\
\cline { 2 - 3 } & $\mathrm{t}$ statistics & 117 \\
\cline { 2 - 3 } & $\mathrm{DF}$ & 9.1082 \\
\cline { 2 - 3 } & $p$-value (2-tailed) & 115 \\
\hline
\end{tabular}

The p-value equals 0.000 which indicates that the observations are inconsistent with the null hypothesis (The null hypothesis states that there is no relationship between data availability and HRA adop-tion); the null hypothesis can be rejected (Table 5).

$H_{5}$ : There is a relationship between the effort expectancy and the adoption of using HR analytics.

Table 6: Correlation between effort expectancy and HRA adoption

\begin{tabular}{|l|c|c|}
\hline \multicolumn{1}{|c|}{} & Effort expectancy \\
\hline \multirow{3}{*}{$\begin{array}{l}\text { Adoption } \\
\text { of HRA }\end{array}$} & $\begin{array}{c}\text { Pearson Correlation } \\
\text { Coefficient }\end{array}$ & 0.6403 \\
\cline { 2 - 3 } & $\mathrm{n}$ & 117 \\
\cline { 2 - 3 } & $\mathrm{t}$ statistics & 8.9393 \\
\cline { 2 - 3 } & $\mathrm{DF}$ & 115 \\
\cline { 2 - 3 } & $p$-value (2-tailed) & 0.0000 \\
\hline
\end{tabular}

As shown in the table above, the Pearson correlation coefficient values between the two variables equal 0.6403 which indicates a positive relationship between the effort expectancy factor and the adoption of HR analytics. The p-value equals 0.000 which indicates that the observations are inconsistent with the null hypothesis (The null hypothesis states that there is no relationship between effort expectancy and HRA adoption), the null hypothesis can be rejected (Table 6).

$H_{6}:$ There is a relationship between the performance expectancy and the adoption of using HR analytics.

As shown in the table above, if Pearson correlation coefficient values between the two variables equal 0.5929 which indicates a positive relationship between the performance expectancy factor and the adoption of HR analytics (Table 7).
Table 7: Correlation between performance expectancy and HRA adoption

\begin{tabular}{|c|c|c|}
\hline \multicolumn{2}{|c|}{} & $\begin{array}{c}\text { Performance } \\
\text { expectancy }\end{array}$ \\
\hline \multirow{4}{*}{$\begin{array}{l}\text { Adoption } \\
\text { of HRA }\end{array}$} & $\begin{array}{c}\text { Pearson Correlation } \\
\text { Coefficient }\end{array}$ & 0.5929 \\
\cline { 2 - 3 } & $\mathrm{n}$ & 117 \\
\cline { 2 - 3 } & $\mathrm{t}$ statistics & 7.8951 \\
\cline { 2 - 3 } & DF & 115 \\
\cline { 2 - 3 } & $p$-value (2-tailed) & 0.0000 \\
\hline
\end{tabular}

The p-value equals 0.000 which indicates that the observations are inconsistent with the null hypothesis (The null hypothesis states that there is no relationship between performance expectancy and HRA adoption), the null hypothesis can be rejected (Table 7).

\section{DISCUSSION:}

As stated by many publishers, the use of HR analytics increases an organization's productivity and enhances its overall value, then why HR professionals are not involved in analytics, specifically HR analytics? The purpose of the present research was to discover the hindrance and barriers of adopting HR analytics among Saudi HR professionals. This study discusses the adoption of technological innovation theory at the individual-level and the adoption of HR analytics by HR professionals HRM field. Having the necessary tools to perform analytics is an important factor that has a great impact on the decision of HR professionals to use HR analytics. The availability of tools means having the right systems or applications, along with having the necessary skills to understand and perform the required tasks on the systems (Mondore et al., 2011).

According to Rogers, (2010), the first step of the process of accepting or rejecting the adoption of the innovation is the knowledge step. Individuals at this step are seeking to understand and learn more about innovation. In this research, the importance of tool availability in the decision of adopting HR analytics can be demonstrated through the estimated correlation between HRA adoption and tool availability. The correlation coefficient revealed a positive relationship $(\mathrm{r} \approx 0.6673)$ and it was the highest among other 
factors. This research has found that the perception of HR professionals of how simple using HR analytics has a great impact on adopting the use of it. In other words, if $\mathrm{HR}$ professionals are expecting that the adoption of HR analytics requires very little effort, it would be more likely that they will use it (Venkatesh et al., 2012).

In this study, around $71 \%$ of the respondents claim that they adopt HR analytics (the level of adoption varies), and approximately $63.84 \%$ of the respondents believe that learning and using HR analytics is not difficult. The perception of HR professionals of how the adoption of HR analytics is willing to increase their job performance is another factor that impacts their decision of adopting the use of HR analytics. Performance expectancy can be explained as; the level of an individual's willingness or unwillingness to use an application if they believe it will enhance performing their tasks.

Previous papers have shown that the impact of performance expectancy on an individual's intention of using technology is very high (Davis, 1989). Even though the correlation coefficient between the HRA adoption and performance expectancy was the lowest compared with other factors, it was estimated at 0.592 which indicates a positive relationship between the two variables.

\section{CONCLUSION AND RECOMMENDATIONS:}

This study has also found that HR professionals who believe that they are capable of learning and performing the required process of analytics are more likely to adopt using it. The correlation coefficient between self-efficacy and HR analytics adoption was the second-highest score in this study, which indicates the high contribution of this factor on the HR professionnals' decision of adoption. Data availability is another important factor of this study. The correlation coefficient between data availability and the adoption of using HRA was estimated as (.647) which is considered as an indicator of a positive relationship among the two factors.

Applying this study to a larger sample is highly recommended as it may present different results. Another recommendation for further studies is to increase the UniversePG I www.universepg.com scope and cover different Saudi HR professionals working in different areas. This study also could include larger diversity and international scope. It is recommended for further studies also to measure other factors external and demographic factors and not being limited to only the factors of the unified theory of acceptance and use of technology.

\section{ACKNOWLEDGEMENT:}

Thanks to all who contributed and participated in a questionnaire filling as a respondent, data processing, collection, and management.

\section{CONFLICTS OF INTEREST:}

I am not expecting any dispute from any other parties. There is no potential conflict of interest reported by the authors.

\section{REFERENCES:}

1) Acemoglu, D., \& Restrepo, P. (2019). Automation and new tasks: How technology displaces and reinstates labor. Journal of Economic Perspectives, 33(2), 3-30.

https://doi.org/10.1257/jep.33.2.3

2) Al-Asmari, M. (2008). Saudi labor force: Challenges and ambitions. JKAU: Arts \& $\mathrm{Hu}$ manities, 16(2), 19-59.

https://www.kau.edu.sa/Show_Res.aspx?Site_ID $=320 \&$ Lng $=\mathrm{EN} \& \mathrm{RN}=51275$

3) Andrijević Matovac, V., Bilas, V., \& Franc, S. (2010). Understanding the importance of human capital and labor market competitiveness in the EU candidate countries and selected EU members. Ekonomska misaoipraksa, 2, 359-382. https://hrcak.srce.hr/62319

4) Angrave, D., Charlwood, A., Kirkpatrick, I., Lawrence, M., \& Stuart, M. (2016). HR and analytics: why HR is set to fail the big data challenge. Human resource management $j$., 26(1), 1-11.

https://doi.org/10.1111/1748-8583.12090

5) BarNir, A., Gallaugher, J. M., \& Auger, P. (2003). Business process digitization, strategy, and the impact of firm age and size: the case of the magazine publishing industry. Journal of Business Venturing, 18(6), 789-814. https://doi.org/10.1016/S0883-9026(03)00030-2 
6) Davis, F. D. (1989). Perceived usefulness, perceived ease of use, and user acceptance of information technology. MIS quarterly, 319340. https://doi.org/10.2307/249008

7) Delery, J. E., \& Roumpi, D. (2017). Strategic human resource management, human capital and competitive advantage: is the field going in circles? Human resource management journal, 27(1), 1-21. https://doi.org/10.1111/1748-8583.12137

8) Fitz-Enz, J. (2010). The new HR analytics: American Management Association. Available online at:

http://u.camdemy.com/sysdata/doc/4/4f6fc50c64 b48b94/pdf.pdf

9) Fitz-Enz, J., \& John Mattox, I. (2014). Predictive analytics for human resources: John Wiley \& Sons. Available online at:

https://www.wiley.com/en-us/Predictive+Analyti cs+for+Human+Resources-p-9781118893678

10) Guest, D., \& Conway, N. (2011). The impact of HR practices, HR effectiveness and a 'strong HR system'on organisational outcomes: a stakeholder perspective. The International Journal of Human Resource Management, 22(8), 1686-1702.

https://doi.org/10.1080/09585192.2011.565657

11) Hoque MT, Alam J, Burman SD, and Alam QN. (2020). Impact of macroeconomic and bank specific variables on spread of interest rate: a study of listed commercial banks in Bangladesh, Can. J. Bus. Inf. Stud., 2(6), 148156. ttps://doi.org/10.34104/cjbis.020.01480156

12) Kim, J., Dibrell, C., Kraft, E., \& Marshall, D. (2021). Data analytics and performance: The moderating role of intuition-based HR management in major league baseball. Journal of Business Research, 122, 204-216. https://doi.org/10.1016/j.jbusres.2020.08.057

13) Kochan, T. A. (2004). Restoring trust in the human resource management profession. Asia Pacific Journal of Human Resources, 42(2), 132-146. https://doi.org/10.1177/1038411104045352

14) Kochan, T. A. (2007). Social legitimacy of the HRM profession: A US perspective. The
Oxford handbook of HRM, 599-619. https://doi.org/10.1093/OXFORDHB\%2F97801 99547029.003.0029

15) Levenson, A., \& Fink, A. (2017). Human capital analytics: too much data and analysis, not enough models and business insights. Journal of Organizational Effectiveness: People and Performance. https://doi.org/10.1108/JOEPP-03-2017-0029

16) Milon M., (2019). Present scenario of human resource management (HRM) practices in the life insurance companies: Bangladesh perspective. Can. J. Bus. Inf. Stud., 1(6), 17-27. https://doi.org/10.34104/cjbis.019.01727

17) Minbaeva, D. B. (2018). Building credible human capital analytics for organizational competitive advantage. Hum. Res. Manag, 57 (3), 701-713. https://doi.org/10.1002/hrm.21848

18) Mondore, S., Douthitt, S., \& Carson, M. (2011). Maximizing the impact and effectiveness of HR analytics to drive business outcomes. People and Strategy, 34(2), 20.

19) Parry, E., \& Strohmeier, S. (2014). HRM in the digital age-digital changes and challenges of the HR profession. Employee relations. https://doi.org/10.1108/ER-03-2014-0032

20) Pradana, M., Pérez-Luño, A., \& FuentesBlasco, M. (2020). Innovation as the key to gain performance from absorptive capacity and human capital. Technology Analysis \& Strategic Management, 32(7), 822-834. https://doi.org/10.1080/09537325.2020.1714578

21) Rasmussen, T., \& Ulrich, D. (2015). Learning from practice: how HR analytics avoids being a management fad. Organizational dynamics, 44(3), 236-242. https://doi.org/10.1016/j.orgdyn.2015.05.008

22) Rogers, E.M. (2010). Diffusion of Innovations. $4^{\text {th }}$ Edition, Simon and Schuster, New York. https://www.simonandschuster.com/books/Diffu sion-of-Innovations-4th-Edition/Everett-M-Rog ers/9781451602470

23) Rucci, A. J. (1998). Should HR survive? A profession at the crossroads. Human Resource Management (1986-1998), 36(1), 169. https://doi.org/10.1002/(SICI)1099-050X(19972 1)36:1\%3C169::AID-HRM27\%3E3.0.CO;2-5 
24) Strassmann, P. A. (1985). Information payoff: The transformation of work in the electronic age: Strassmann, Inc.

https://catalogue.nla.gov.au/Record/2876506

25) Tzafrir, S. S., Meshoulam, I., \& Baruch, Y. (2007). HRM in Israel: New challenges. The International Journal of Human Resource Management, 18(1), 114-131. https://doi.org/10.1080/09585190601068425

26) Ulrich, D., Younger, J., Brockbank, W., \& Ulrich, M. D. (2013). The state of the HR profession. Human Resource Management, 52(3), 457-471. https://doi.org/10.1002/hrm.21536
27) Venkatesh, V., Thong, J. Y., \& Xu, X. (2012). Consumer acceptance and use of information technology: extending the unified theory of acceptance and use of technology. MIS quarterly, 157-178.

https://doi.org/10.2307/41410412

28) Zhou, Y., Liu, G., Chang, X., \& Wang, L. (2021). The impact of HRM digitalization on firm performance: investigating three-way interactions. Asia Pacific Journal of Human Resources, 59(1), 20-43.

https://doi.org/10.1111/1744-7941.12258

Citation: Alsuliman BRA, and Elrayah M. (2021). The Reasons that affect the implementation of HR analytics among HR professionals, Can. J. Bus. Inf. Stud., 3(2), 29-37. https://doi.org/10.34104/cjbis.021.029037 (C) () 